\title{
Effect of processing whole cottonseed on nutrient digestibility and ruminal fermentation in dairy cows*
}

\author{
P. Chen, P. Ji, Z.J. Cao and S.L. Li ${ }^{1}$ \\ State Key Laboratory of Animal Nutrition, College of Animal Science \& Technology, \\ China Agricultural University \\ Beijing 100094, P.R. China
}

\begin{abstract}
Four ruminally cannulated Holstein cows were used in a $4 \times 4$ Latin square design to determine the effect of feeding linted, delinted and extruded linted whole cottonseed (WCS) on nutrient digestibility and ruminal fermentation. Result showed that crude protein digestibility was lower in linted and delinted WCS treatments than control and extruded linted WCS treatment. Cows fed extruded delinted WCS had the highest digestibility of neutral detergent fibre compared with those fed the other diets. The inclusion of processing WCS did not alter ruminal $\mathrm{pH}$ and ruminal total and molar proportion of volatile fatty acids, however, feeding delinted WCS reduced the ruminal ammonia nitrogen concentration and acetic:propionic acid ratio.
\end{abstract}

KEY WORDS: cottonseed, processing, nutrient digestibility, ruminal fermentation, dairy cows

\section{INTRODUCTION}

The high net energy lactation $\left(\mathrm{NE}_{\mathrm{L}}\right)$ concentration (about $2.22 \mathrm{Mcal} / \mathrm{kg}$ ) of whole cottonseed (WCS) combined with its balanced nutrient composition makes it a valuable feedstuff for high-producing dairy cows (NRC, 2001). The oil in the seed is believed to be slowly release when the intact seed is masticated, which may help decrease the detrimental effects on rumen fermentation (Gonthier et al., 2004).

Two types of WCS are supplied by the cotton gin industry to dairy farm. With high levels of effective NDF, CP and fatty acid, linted WCS serves concurrently as a forage replacer and a concentrate (Harvatine et al., 2002). Although contributing

\footnotetext{
* Supported by the National Dairy Key Technologies R \& D Programme for the 11th Five-Year Plan, Grant No. 2006BAD04A03

${ }^{1}$ Corresponding author: e-mail: lisheng0677@vip.sina.com
} 
to fibre effectiveness in the rumen, lint increases bulkiness and makes it difficult to handle. Delinted WCS has been explored for improving handling and nutritional value of linted WCS (Pires et al., 1997). Heat treatment is commonly used to decrease the solubility of protein by blocking reactive sites for microbial proteolytic enzymes (Gonthier et al., 2004). Pires et al. (1997) reported that roasted WCS offered the same nutritional benefits as WCS for nutrition utilization and decreases cottonseed protein degradation in the rumen.

However, information on the effects of extruded linted WCS on nutrient utilization and rumen fermentation by dairy cows was not available. The objective of this study was to compare the effects of different processing WCS (linted, delinted and extruded delinted) on total tract nutrient apparent digestibility and ruminal fermentation for midlactation dairy cows.

\section{MATERIAL AND METHODS}

Four ruminally cannulated Holstein cows averaging $105( \pm 28)$ days in milk (DIM) were used in a $4 \times 4$ Latin square design with four 3 -wk periods. The first $16 \mathrm{~d}$ of each period were for adaptation to diets and the last $5 \mathrm{~d}$ were for sample collection. The cows were kept in stalls, bedded on rubber mats, with free access to water. Cows were milked three times daily.

Dietary treatments consisted of 1. a control diet with no WCS (CON), 2. a linted WCS diet (LCS), 3. a delinted WCS diet (DCS), and 4. an extruded delinted WCS diet (ECS). All diets were formulated to meet nutrient requirements of midlactating dairy cows (NRC, 2001). The ingredients and chemical composition of the four dietary treatments were shown in Table 1.

Diets were fed as total mixed ration (TMR) for ad libitum intake three times daily, and amounts fed and refused were recorded daily for each animal. The DM content of maize silage was measured weekly, and the amounts of forages fed adjusted to maintain a constant proportion of the dietary dry matter (DM).

Total faeces were taken and weighed every day during the collection period. Subsamples of faeces were mixed, dried $\left(60^{\circ} \mathrm{C}\right)$, ground $(1 \mathrm{~mm}$ screen of a standard Wiley mill). Crude protein (CP), DM and ether extract (EE) were analysed according to AOAC (1997) and organic matter (OM) was calculated as the weight lost after ashing for at least $6 \mathrm{~h}$ at $550^{\circ} \mathrm{C}$. Both neutral detergent fibre (NDF) and acid detergent fibre (ADF) were analysed using the modified filter bag method of Van Soest et al. (1991).

Samples of ruminal digesta were collected from each cow on the last 3 days of each period prior to morning feeding $(0 \mathrm{~h})$ and sampled at an interval of 2 for $24 \mathrm{~h}$ daily. The whole rumen fluid was squeezed through 4 layers of cheesecloth. Following immediate determination of $\mathrm{pH}$ using a portable $\mathrm{pH}$ meter $(\mathrm{pH} / \mathrm{temp}$ 
meter 199 Model No 3D; Fisher Scientific, Pittsburgh, PA), a portion of the ruminal fluid was collected to measure ammonia nitrogen concentration $\left(\mathrm{NH}_{3}-\mathrm{N}\right)$ by the procedure described by Broderick and Kang (1980). The other portion of the filtrate was acidified with $25 \%$ metaphosphoric acid, and then frozen at $-20^{\circ} \mathrm{C}$ for volatile fatty acids (VFA) analysis according to Erwin et al. (1961). Concentrations of VFA were determined using gas chromatography (6890 N, Agilent technologies) equipped with a $30 \mathrm{~m}$ HP-INNOWax 19091N-213 (Agilent) capillary column $(0.32 \mathrm{~mm}$ i.d. and $0.50 \mathrm{~mm}$ film thickness). The chromatograph oven was programmed as follows: $120^{\circ} \mathrm{C}$ for $3 \mathrm{~min}, 10^{\circ} \mathrm{C} / \mathrm{min}$ increment to $180^{\circ} \mathrm{C}$, and then was held for $1 \mathrm{~min}$. The injector and detector were maintained at $220^{\circ} \mathrm{C}$ and $250^{\circ} \mathrm{C}$, respectively. Nitrogen was used as carrier gas (flow rate $2.0 \mathrm{ml} / \mathrm{min}$ ).

Table 1. Ingredients and chemical composition of different diets and different processing WCS ${ }^{1}$

\begin{tabular}{lrrrrrrr}
\hline \multirow{2}{*}{ Item } & \multicolumn{5}{c}{ Experimental treatments } & & \multicolumn{2}{c}{ Processing WCS } \\
\cline { 2 - 4 } Ingredient, \% DM basis & CON & LCS & DCS & ECS & & linted delinted extruded \\
\hline maize silage & 23.94 & 23.73 & 23.74 & 23.75 & & \\
lucerne, dry & 16.63 & 16.48 & 16.50 & 16.50 & & \\
Chinese wild rye, dry & 11.00 & 8.72 & 8.73 & 8.73 & & \\
maize, ground shelled & 27.03 & 24.37 & 24.38 & 24.39 & \\
soyabean meal & 5.63 & 4.71 & 4.71 & 4.71 & \\
wheat bran & 5.85 & 8.14 & 8.15 & 8.15 & \\
cottonseed meal & 7.19 & -- & -- & -- & \\
linted WCS & -- & 11.01 & -- & -- & \\
delinted WCS & -- & -- & 10.95 & -- & & \\
extruded delinted WCS & -- & -- & -- & 10.93 & \\
salt $(\mathrm{NaCl})$ & 0.61 & 0.63 & 0.63 & 0.63 & \\
Premix & 2.12 & 2.21 & 2.21 & 2.21 &
\end{tabular}

Chemical composition of the diets and processing WCS

\begin{tabular}{lrrrrrrr}
$\mathrm{NE}_{\mathrm{L}}, \mathrm{Mcal} / \mathrm{kg}^{3} \mathrm{DM}$ & 1.55 & 1.57 & 1.57 & 1.57 & & & \\
$\mathrm{OM}, \%$ of DM & 96.01 & 96.16 & 95.91 & 96.25 & 94.93 & 93.64 & 93.87 \\
$\mathrm{CP}, \%$ of DM & 15.04 & 14.82 & 14.85 & 14.92 & 23.50 & 24.13 & 24.70 \\
$\mathrm{NDF}, \%$ of DM & 36.03 & 37.87 & 36.93 & 36.74 & 53.40 & 45.03 & 47.36 \\
$\mathrm{ADF}, \%$ of DM & 23.68 & 25.21 & 24.03 & 23.97 & 39.60 & 36.38 & 36.90 \\
$\mathrm{EE}, \%$ of DM & 3.21 & 5.14 & 5.15 & 5.06 & 18.90 & 19.11 & 18.30 \\
\hline
\end{tabular}

${ }^{1}$ CON-control, LWC-linted WCS, DWC-delinted WCS, EWC-extruded WCS; ${ }^{2}$ contained, $\mathrm{mg} / \mathrm{kg}$ : $\mathrm{I}_{2}$ 30; Fe 800; Cu 500; Mn 600; Zn 2000; Se 20; Co 10; IU/kg: vit. A 150,000; vit. D 25,000; vit. E $1000 ;{ }^{3}$ estimated using $\mathrm{NE}_{\mathrm{L}}$ values for feedstuffs from NRC (2001)

Data analysed using the GLM procedure of SAS (1999) for Latin square with affects of periods and treatments, the random effect was cow. Significance was declared at $\mathrm{P}<0.05$. A trend was considered to exist if $0.05 \leq \mathrm{P}<0.10$. 


\section{RESULTS AND DISCUSSION}

Dairy cow dry matter intake (DMI) was unaffected by different treatments $(\mathrm{P}>0.05$; Table 2). Apparent digestibility of $\mathrm{CP}$ was lower for the LCS and DCS diets than for CON and ECS diets $(\mathrm{P}<0.05)$. The fibre form lint and hulls caused the intact seed of LCS and DCS to reside in the rumen longer than ECS, thereby increasing the degradability of $\mathrm{CP}$ and decreased the $\mathrm{CP}$ digestibility in lower tract (Pires et al., 1997; Moreira et al., 2004). Furthermore,

Table 2. Dry matter intake and nutrient apparent digestibility of dairy cows fed different diets ${ }^{1}$

\begin{tabular}{|c|c|c|c|c|c|c|}
\hline \multirow{2}{*}{ Item } & \multicolumn{4}{|c|}{ Experimental treatments } & \multirow{2}{*}{ SEM } & \multirow{2}{*}{$\mathrm{P}$} \\
\hline & $\mathrm{CON}$ & LCS & DCS & ECS & & \\
\hline DM intake, $\mathrm{kg} / \mathrm{d}$ & 15.96 & 15.98 & 16.49 & 16.92 & 0.48 & 0.58 \\
\hline \multicolumn{7}{|c|}{ Total tract apparent digestibility, $\%$} \\
\hline $\mathrm{DM}$ & 61.97 & 61.89 & 61.97 & 62.57 & 0.60 & 0.49 \\
\hline $\mathrm{OM}$ & 62.54 & 62.41 & 62.26 & 63.27 & 0.57 & 0.34 \\
\hline $\mathrm{CP}$ & $67.22^{\mathrm{a}}$ & $64.01^{\mathrm{b}}$ & $65.04^{\mathrm{b}}$ & $68.17^{\mathrm{a}}$ & 0.48 & 0.04 \\
\hline $\mathrm{NDF}$ & 52.34 & 56.50 & 54.21 & 58.50 & 1.89 & 0.09 \\
\hline $\mathrm{ADF}$ & 44.19 & 49.11 & 47.23 & 51.44 & 1.65 & 0.13 \\
\hline $\mathrm{EE}$ & 53.94 & 56.46 & 54.42 & 55.75 & 2.37 & 0.60 \\
\hline
\end{tabular}

${ }^{1}$ see Table 1

${ }^{\mathrm{a}, \mathrm{b}}$ means within a row with different superscripts $\operatorname{differ}(\mathrm{P}<0.05)$

heated and ground treatment of the extruded WCS decreased the degradation in rumen and increased surface area for contact with proteases to increase $\mathrm{CP}$ total tract digestibility. There was a trend that diets supplemented with extruded WCS could increase NDF digestibility $(\mathrm{P}<0.1)$. This result was in agreement with previous reports (Pires et al., 1997; Reveneau et al., 2005; Sullivan et al., 2005). The decrease in nutrient solubility and degradability of extruded WCS may increase passage of fibre of WCS origin to the abomasum. The DM, OM and EE digestibilities were similar among treatments $(\mathrm{P}>0.05)$.

For ruminal fermentation characteristics, no treatment $\times$ time interaction was significant $(\mathrm{P}>0.05)$. Therefore, means for ruminal $\mathrm{pH} \mathrm{NH}_{3}-\mathrm{N}$ and VFA were averaged over all times (Table 3 ). The ruminal $\mathrm{pH}$ was similar in cows fed four diets and within an acceptable range to maintain a healthy rumen environment (NRC, 2001).

Ruminal $\mathrm{NH}_{3}-\mathrm{N}$ concentration was significantly increased in cows fed ECS diet and reduced for DCS diet compared with CON $(\mathrm{P}<0.05)$. Extrusion of the cottonseed frees the seed oil and is likely associated with negative effects on rumen microbial growth (Mabjeesh et al., 2000) and $\mathrm{NH}_{3}-\mathrm{N}$ utilization in rumen. 
Delinted WCS tends to sink in the rumen, is masticated less and digested less in the rumen (Sullivan et al., 2005), therefore, produces less $\mathrm{NH}_{3}-\mathrm{N}$.

Total and molar proportions of VFA were not affected by different dietary treatments $(\mathrm{P}>0.05)$. However, cows fed different processing WCS diets had a trend to decrease the acetic acid:propionic acid ratio relative to $\operatorname{CON}(\mathrm{P}<0.1)$. Previous studies have reported a decrease in acetic acid:propionic acid ratio with increasing unsaturation of the supplemented fat (Oldick and Firkins, 2000) or with processing of oilseed (Gonthier et al., 2004). In this study, the addition of processing WCS supplied less fermentable carbohydrate available for acetic acid production, which probably caused a decrease of acetic:propionic acid ratio, however, the amount of fat in WCS was not large enough or the lipolysis rate was not fast enough to build up concentrations of free FA to alter microbial processes.

Table 3. Ruminal fermentation characteristics of dairy cows fed different $\operatorname{diets}^{1}$

\begin{tabular}{|c|c|c|c|c|c|c|}
\hline \multirow{2}{*}{ Item } & \multicolumn{4}{|c|}{ Experimental treatments } & \multirow{2}{*}{ SEM } & \multirow{2}{*}{$\mathrm{P}$} \\
\hline & $\mathrm{CON}$ & LCS & DCS & ECS & & \\
\hline $\mathrm{pH}$ & 6.71 & 6.77 & 6.75 & 6.78 & 0.04 & 0.40 \\
\hline $\mathrm{NH}_{3}-\mathrm{N}, \mathrm{mg} / \mathrm{dl}$ & $9.83^{\mathrm{ab}}$ & $9.15^{\mathrm{bc}}$ & $8.32^{\mathrm{c}}$ & $10.56^{\mathrm{a}}$ & 0.34 & $<0.001$ \\
\hline Total VFA, mmol/l & 128.94 & 121.28 & 123.40 & 120.09 & 5.43 & 0.71 \\
\hline \multicolumn{7}{|l|}{$V F A, \%$} \\
\hline $\operatorname{acetic} \operatorname{acid}(\mathrm{A})$ & 69.01 & 68.87 & 68.32 & 68.24 & 0.34 & 0.16 \\
\hline propionic acid (P) & 18.01 & 18.51 & 18.85 & 18.46 & 0.27 & 0.26 \\
\hline butyric acid & 0.83 & 0.93 & 0.93 & 1.12 & 0.11 & 0.19 \\
\hline isobutyric acid & 9.98 & 9.66 & 9.97 & 9.82 & 0.16 & 0.48 \\
\hline valeric acid & 1.19 & 1.01 & 0.94 & 1.17 & 0.07 & 0.12 \\
\hline isovaleric acid & 0.98 & 1.02 & 0.99 & 1.19 & 0.09 & 0.17 \\
\hline A: P & 3.83 & 3.72 & 3.62 & 3.70 & 0.06 & 0.08 \\
\hline
\end{tabular}

${ }^{1}$ see Table 1

${ }^{\mathrm{a}, \mathrm{b}}$ means within a row with different superscripts differ $(\mathrm{P}<0.05)$

\section{CONCLUSIONS}

Addition of processing cottonseed to dairy cow rations in midlactation up to $11 \%$ of dietary DM had no adverse effect on intake, or ruminal fermentation. Extruded delinted whole cottonseed increased the CP total tract apparent digestibility and trended to elevate the NDF digestibility relative linted and delinted whole cottonseed treatments. Extrusion could be used to increase whole cottonseed nutrient utilization for dairy cows. 


\section{REFERNECES}

AOAC., 1997. Association of Official Analytical Chemists, Official Methods of Analysis. 16 $6^{\text {th }}$ Edition. Gaithersburg, MD

Broderick G.A., Kang J.H., 1980. Automated simultaneous determination of ammonia and amino acids in ruminal fluids and in vitro media. J. Dairy Sci. 63, 64-75

Erwin E.S., Marco G.J., Emery E.M., 1961. Volatile fatty acid analysis of blood and rumen fluid by gas chromatography. J. Dairy Sci. 44, 1768-1777

Gonthier C., Mustafa A.F., Berthiaume R., Petit H.V., Martineau R., Ouellet D.R., 2004. Effects of feeding micronized and extruded flaxseed on ruminal fermentation and nutrient utilization by dairy cows. J. Dairy Sci. 87, 1854-1863

Harvatine D.I., Firkins J.L., Eastridge M.L., 2002. Whole linted cottonseed as a forage substitute fed with ground or steam-flaked corn: digestibility and performance. J. Dairy Sci. 85, 1976-1987

Mabjeesh S.J., Galindez J., Kroll O., Arieli A., 2000. The effect of roasting nonlinted whole cottonseed on milk production by dairy cows. J. Dairy Sci. 83, 2557-2563

Moreira V.R., Satter L.D., Harding B., 2004. Comparison of conventional linted cottonseed and mechanically delinted cottonseed in diets for dairy cows. J. Dairy Sci. 87, 131-138

NRC, 2001. Nutrient Requirements of Dairy Cattle. 7th Edition. National Academy of Sciences. Washington, DC

Oldick B.S., Firkins J.L., 2000. Effects of degree of fat saturation on fiber digestion and microbial protein synthesis when diets are fed twelve times daily. J. Anim. Sci. 78, 2412-2420

Pires A.V., Eastridge M.L., Firkins J.L., Lin Y.C., 1997. Effects of heat treatment and physical processing of cottonseed on nutrient digestibility and production performance by lactating cows. J. Dairy Sci. 80, 1685-1694

Reveneau C., Ribeiro C.V.D.M., Eastridge M.L., St-Pierre N.R., Firkins J.L., 2005. Processing whole cottonseed moderates fatty acid metabolism and improves performance by dairy cows. J. Dairy Sci. 88, 4342-4355

SAS, 1999. SAS User's Guide: Statistics. Version 8 Ed. SAS Institute Inc. Cary, NC

Sullivan H.M., Bernard J.K., Amos H.E., 2005. Ruminal fermentation and amino acid flow in Holstein steers fed whole cottonseed with elevated concentrations of free fatty acids in the oil. J. Dairy Sci. 88, 690-697

Van Soest P.J., Robertson J.B., Lewis B.A., 1991. Methods for dietary fiber, neutral detergent fiber, and nonstarch polysaccharides in relation to animal nutrition. J. Dairy Sci. 74, 3583-3597 